\title{
Sequential Trial of Effect of Phenobarbitone on Serum Bilirubin of Preterm Infants
}

\author{
F. CARSWELL, M. M. KERR, and I. R. DUNSMORE \\ From the Department of Child Health and the Department of Statistics, University of Glasgow
}

\begin{abstract}
Carswell, F., Kerr, M. M., and Dunsmore, I. R. (1972). Archives of Disease in Childhood, 47, 021. Sequential trial of effect of phenobarbitone on serum bilirubin of preterm infants. (1) Phenobarbitone in a dose of $8 \mathrm{mg} / \mathrm{kg}$ per day was given in twice-daily intramuscular doses to preterm infants with a gestational age of 36 completed weeks or less. The phenobarbitone was started within the first 24 hours after birth. (2) The peak serum bilirubin levels of these infants and matched, randomly selected, control infants were compared sequentially. A significantly lower $(P<0.05)$ peak bilirubin level was found in the treated group. (3) This lower level of serum bilirubin may be less liable to produce neurological damage in preterm infants.
\end{abstract}

The recent increased survival of low birthweight infants (Stahlman, 1969; Rawlings et al., 1971) has been associated with increased concern for the eventual mental state of these children. Children who develop severe hyperbilirubinaemia are liable to have later evidence of brain damage (Boggs, Hardy, and Frazier, 1967; Hyman et al., 1969; Culley et al., 1970). This brain damage becomes more likely when the peak serum bilirubin level rises above $16 \mathrm{mg} / 100 \mathrm{ml}$. It is more liable to occur in low birthweight children and has been found at necropsy in low birthweight children whose peak serum bilirubin level was less than $10 \mathrm{mg} /$ $100 \mathrm{ml}$ (Gartner et al., 1970; Ackerman, Dyer, and Leydorf, 1970). Preterm infants are particularly liable to develop both the hyperbilirubinaemia and the consequential brain damage. Accordingly a number of therapies have been devised to reduce this hyperbilirubinaemia.

Glucuronyl transferase is the enzyme which catalyses the rate-limiting step in the transformation of the lipid soluble, potentially neurotoxic bilirubin, to the water soluble, harmless bilirubin glucuronide. This enzyme activity is low in newborn animals (Brown and Zuelzer, 1958) but can be increased by phenobarbitone (Catz and Yaffe, 1962). Several trials have been performed to assess the efficiency of phenobarbitone in reducing the serum bilirubin levels in neonates (e.g. Cunningham, Mace, and Peters, 1969; Levin, McMullin, and Mobarak,

Received 21 January 1972.
1970; Stern et al., 1970). Conney (1967) and Arias (1970) suggest that phenobarbitone is unlikely to be effective after less than 3 days therapy as increased glucuronyl transferase activity would only begin to appear after that time. This agrees with Stern et al.'s (1970) results in term neonates. As the peak bilirubin level is reached in neonates between the 4th and 8th day of life, trials which start phenobarbitone after the appearance of jaundice or high serum bilirubin levels are unlikely to show benefit. Trials of phenobarbitone which start the drug before birth (Ramboer, Thompson, and Williams, 1969; Maurer et al., 1968; Trolle, 1968a) have shown a reduction in the peak bilirubin levels attained by treated children. However, premature delivery is commonly unexpected and unless one gave all mothers phenobarbitone from the 28th week of gestation, it would seem easier to treat the children from birth. Trolle (1968b) showed that, while phenobarbitone reduced the serum bilirubin levels of term infants, it was only effective in those infants with low bilirubin levels. In an addendum to that paper he showed that the phenobarbitone was effective in reducing the proportion of premature infants who have high bilirubin levels. Ramboer et al. (1969) found phenobarbitone was ineffective when administered orally to term and preterm infants. Yeung and Field (1969) showed that oral phenobarbitone reduced the level of hyperbilirubinaemia in jaundiced term Chinese babies. We felt that further clinical trials were required to assess the efficacy of phenobarbitone 
in reducing the serum bilirubin levels of preterm infants and accordingly devised the present controlled trial.

\section{Methods}

All infants admitted to the Paediatric Department of the Queen Mother's Hospital within 24 hours of birth with a birthweight of $2.5 \mathrm{~kg}$ or less and with a gestational age of 36 completed weeks or less were included in the trial. Infants with a birthweight of $1.8 \mathrm{~kg}$ or less whose mothers were unsure of their dates were also admitted to the trial. All twins and rhesus-affected infants were excluded from the trial.

Serum bilirubin levels were estimated up to the 10th day of life using the method of Mertz and West (1956). Other relevant clinical data such as the time of the first feed, the presence or absence of infection, bruising, hypoglycaemia, IRDS, and other drug therapies were noted for each infant in the trial. Phenobarbitone was given intramuscularly for the first 7 days of life in a dosage of $8 \mathrm{mg} / \mathrm{kg}$ per day in two divided doses to randomly selected infants. Control and treated infants were compared as they were included in the trial. Only pairs in which both infants survived to at least 8 days of age were considered in the sequential analysis of the difference between the peak bilirubin levels.

The results were analysed by Barnard's sequential ' $t$ ' test (Davies, 1960; Armitage, 1960). From prior knowledge the SD of the difference in the peak bilirubin levels (control-treated) was estimated to be $3.0 \mathrm{mg} /$ $100 \mathrm{ml}$. It was considered that a decrease of half this amount in peak levels would be important, and so we tested for a decrease of $0.5 \mathrm{SD}$ with risks of the two types of error set at 0.05 and 0.20 respectively, i.e. the test assures us that the probability of asserting that the treatment reduces the peak level when in fact it has no effect is at most 0.05 , while the probability of asserting that the treatment has no effect when it in fact does reduce peak level is at most $0 \cdot 20$. The boundary curves in Fig. 1 are then given in Davies (1960).

\section{Results}

After 21 pairs of infants had been included in the sequential analysis and when a total of 74 neonates had been studied, the sequential analysis showed that the treated infants had a significantly lower $(P<0.05)$ peak bilirubin level.

Fig. 1 shows the sequential analysis. Independent statistical analysis (' $t$ ' tests) of the peak levels confirmed that there was a significant difference between the peak levels in the two groups of patients. This difference is not due to phenobarbitone lowering only the levels in mildest affected children as shown in Table $\mathrm{I}$.

TABLE I

\begin{tabular}{c|c|c}
\hline \multirow{2}{*}{$\begin{array}{c}\text { Peak } \\
\text { Serum Bilirubin } \\
\text { Levels }\end{array}$} & \multicolumn{2}{|c}{ No. of Patients } \\
\cline { 2 - 3 } & Treated & Control \\
\hline$>20 \mathrm{mg} / 100 \mathrm{ml}$ & 0 & 1 \\
$>15 \mathrm{mg}<20 \mathrm{mg} / 100 \mathrm{ml}$ & 3 & 4 \\
$>10 \mathrm{mg}<15 \mathrm{mg} / 100 \mathrm{ml}$ & 5 & 11 \\
$<10 \mathrm{mg} / 100 \mathrm{ml}$ & 13 & 5 \\
\hline
\end{tabular}

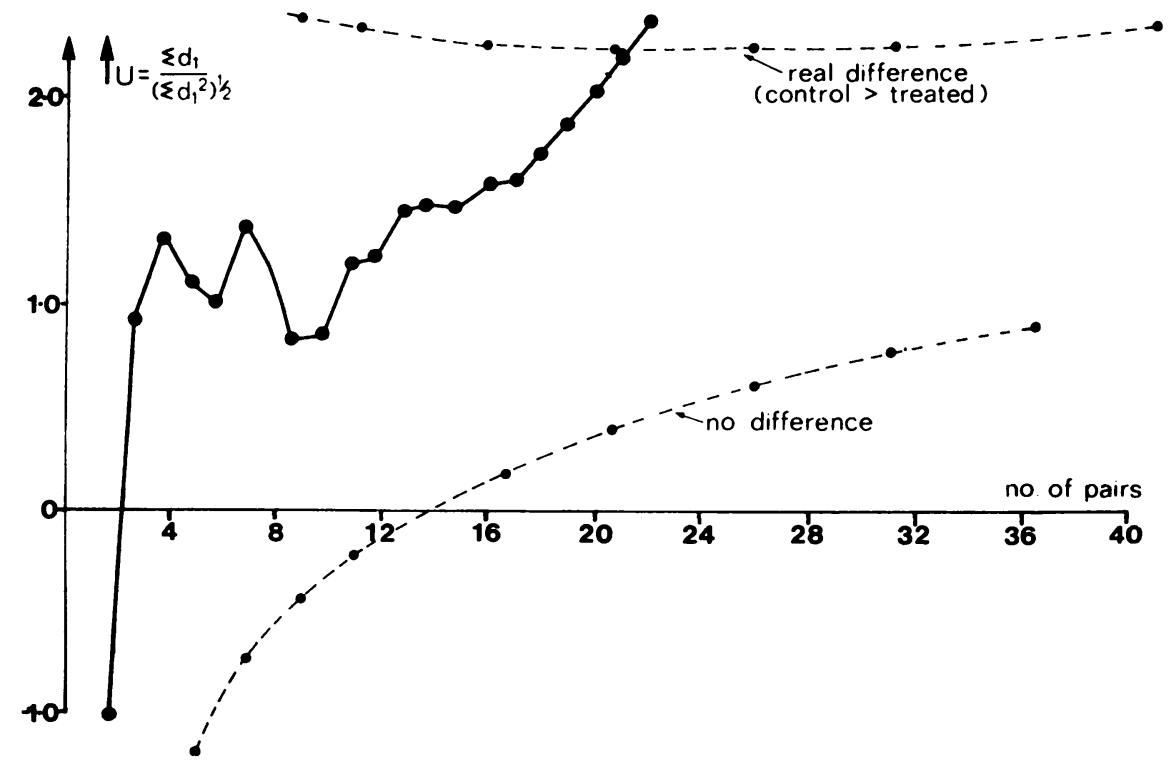

FIG. 1.-Sequential analysis of peak bilirubin levels where $d_{1}=$ difference between peak bilirubin levels in matched pairs of neonates. 
A significantly $(P<0.05)$ higher proportion of children in the untreated group had a peak bilirubin level above $10 \mathrm{mg} / 100 \mathrm{ml}$.

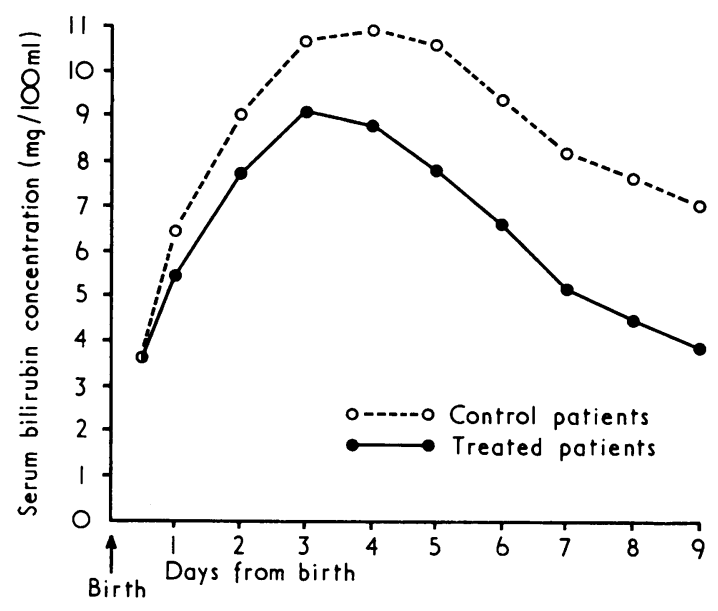

FIG. 2.-Mean bilirubin levels during the trial.

Fig. 2 shows the mean bilirubin levels at the time of estimation in the trial. The separation between the two groups becomes statistically significant at day $5(P<0.05)$ and by day 9 is very significant $(P<0.005)$.

Since the treated and control groups were assigned at random, one hopes that the variables such as gestational age, birthweight, etc. (Table II) would be similarly distributed between the two groups. The analysis shown in Table II shows that this hypothesis is reasonably valid.

It is apparent from Table II that the only other significant difference between the treated and control groups was that the control children tended to be slightly heavier than the treated group (mean birthweight $2.07 \mathrm{~kg}$-control, versus $1.84 \mathrm{~kg}$ treated). This should have tended to reverse the observed difference in peak bilirubin levels.

Patients were excluded from sequential analysis when they or their matched pair died before 8 days of age. When the peak bilirubins of these unmatched patients were compared, the mean levels obtained were $12.7 \mathrm{mg} / 100 \mathrm{ml}$ (control); $11 \cdot 7 \mathrm{mg} /$ $100 \mathrm{ml}$ (treated). This difference is not significant perhaps because there were only 15 surviving patients whose paired patient died. In addition, one of these phenobarbitone-treated patients had a galactokinase deficiency which may have helped to increase the height of the peak to $21 \cdot 8 \mathrm{mg} / 100 \mathrm{ml}$ (Kerr et al., 1971).

Table III compares the causes of death as estab-

TABLE II

Analysis of Differences Between 21 Pairs of Infants Randomly Allocated to Control and Treated Groups

\begin{tabular}{|c|c|c|c|}
\hline Variable Compared & $\begin{array}{l}\text { Treated Group } \\
\text { Mean Value }(\mathbf{x})\end{array}$ & $\begin{array}{l}\text { Untreated Group } \\
\text { Mean Value }(\bar{y})\end{array}$ & $\begin{array}{c}\text { Significance } \\
\text { of Difference (P) }\end{array}$ \\
\hline $\begin{array}{l}\text { Peak bilirubin levels in the serum }(\mathrm{mg} / 100 \mathrm{ml} \text { ) } \\
\text { Age at peak bilirubin level }(\mathrm{dy}) \\
\text { Initial bilirubin level (mg/100 ml) } \\
\text { Gestational age (maternal dates) in wk } \\
\text { Birthweights }(\mathrm{kg}) \\
\text { Sex (no. of males in } 21 \text { subjects) } \\
\text { Time of first oral feed (hr of age) } \\
\text { Bruising ( } 0=\text { none, } 1=\text { some, } 2=\text { a lot) } \\
\text { Patients given prophylactic antibiotics (\%) } \\
\text { Patients with clinical infection (\%) } \\
\text { Incidence of IRDS (\%) } \\
\text { Incidence of hypoglycaemia (\%) }\end{array}$ & $\begin{array}{l}9 \cdot 9 \\
3 \cdot 6 \\
2 \cdot 93 \\
33 \cdot 7 \\
1 \cdot 84 \\
10 \\
21 \cdot 7 \\
0 \cdot 43 \\
62 \\
10 \\
24 \\
19\end{array}$ & $\begin{array}{l}12 \cdot 7 \\
4 \cdot 1 \\
2 \cdot 99 \\
33 \cdot 3 \\
2 \cdot 07 \\
12 \\
18 \cdot 9 \\
0 \cdot 24 \\
52 \\
10 \\
38 \\
19\end{array}$ & $\begin{array}{l}0 \cdot 02-0 \cdot 01 \\
\text { NS } \\
\text { NS } \\
\text { NS } \\
0 \cdot 05-0 \cdot 025 \\
\text { NS } \\
\text { NS } \\
\text { NS } \\
\text { NS } \\
\text { NS } \\
\text { NS } \\
\text { NS }\end{array}$ \\
\hline
\end{tabular}

TABLE III

Causes of Death in 19 Neonates

\begin{tabular}{|c|c|c|c|c|c|c|c|}
\hline & Survived & Dead & IRDS* & IVHt & Infection & $\begin{array}{c}\text { Recurrent } \\
\text { Apnoea }\end{array}$ & $\begin{array}{c}\text { Subdural } \\
\text { Haemorrhage }\end{array}$ \\
\hline $\begin{array}{l}\text { Treated } \\
\text { Untreated }\end{array}$ & $\begin{array}{l}28 \\
29\end{array}$ & $\begin{array}{r}10 \\
9\end{array}$ & $\begin{array}{l}6 \\
5\end{array}$ & $\begin{array}{l}4 \\
5\end{array}$ & $\begin{array}{l}2 \\
0\end{array}$ & $\begin{array}{l}2 \\
1\end{array}$ & $\begin{array}{l}0 \\
1\end{array}$ \\
\hline
\end{tabular}

^IRDS-idiopathic respiratory distress syndrome.

tIVH-intraventricular haemorrhage. 
lished by necropsy and clinical observations (18 cases), or clinical observation alone (1 case).

The brains of those who died were examined routinely at necropsy. One infant who died in the 3rd day of life with proven intraventricular haemorrhage and pneumonia at necropsy, also had definite yellow-staining of the basal ganglia. This male child was born after an unknown duration of gestatation and had a birthweight of $1.07 \mathrm{~kg}$. The child developed severe idiopathic respiratory distress syndrome and died despite therapy including phenobarbitone, intravenous alkali, and negative pressure ventilation. The recorded bilirubin levels in this child were successively $6 \cdot 7,8 \cdot 8,9 \cdot 0$, and $8.7 \mathrm{mg} / 100 \mathrm{ml}$.

\section{Discussion}

This trial appears to have shown that, in Glasgow, administration of phenobarbitone intramuscularly to low birthweight preterm infants reduces the peak bilirubin level they subsequently attain. This is true despite the lower birthweight (Table II), increased handling, the possibly slightly increased risk of infection (Tables II and III), and the increased bruising (Table II) of the treated babies. These factors would tend to increase the peak level of bilirubin obtained in the babies and may imply that a theoretical reduction greater than the $12 \cdot 7-$ $9.9 \mathrm{mg} / 100 \mathrm{ml}$ seen (Table II) could be attained. This reduction in bilirubin level may be associated with a reduction of the brain damage sustained by premature infants when they have a high bilirubin level (Boggs et al., 1967; Culley et al., 1970). The finding of the pathological signs of kernikterus in one child who died in the 3rd day of life emphasizes that the group in which this trial was conducted are at a particular risk for this effect. It also suggests, as this child's 'peak' level of serum bilirubin was $9 \mathrm{mg} / 100 \mathrm{ml}$, that the reduction in bilirubin levels obtained in the trial could be significant with regard to the subsequent mental development of these children. The finding of kernikterus in one child with a peak bilirubin level of $9 \mathrm{mg} / 100 \mathrm{ml}$ confirms that the serum bilirubin level associated with kernikterus in small infants may be lower than those levels found in term infants (Gartner et al., 1970; Ackerman et al., 1970). It may be that measurement of the 'free' bilirubin level will eventually prove a better index of the likelihood of brain damage in infants with hyperbilirubinaemia (Odell, Storey, and Rosenberg, 1970). It is already known that phenobarbitone does not act to lower serum bilirubin levels by displacing indirect bilirubin from its binding sites in the blood (Khanna, Harpur, and Stern, 1969).
Long-term follow-up of the present trial subjects would be worth while to establish the eventual outcome, and this is envisaged. We have not confirmed the finding of Trolle (1968c) that there is a reduction in the first week mortality rate for low birthweight infants after phenobarbitone treatment (Table III).

Phenobarbitone is usually thought to act by increasing the activity of the glucuronyl transferase present in the liver of newborn animals towards adult levels (Brown and Zuelzer, 1958; Catz and Yaffe, 1962). Over 200 drugs are known to induce increased activity of enzymes (Conney, 1967). Both Dicophane (Thompson et al., 1969) and phetharbital (Hunter et al., 1971) have been used successfully to lower levels of unconjugated bilirubin in human patients and could be used in neonates.

Other treatments proposed to reduce neonatal bilirubinaemia include phototherapy (Broughton et al., 1965) and oral administration of Agar gel (Poland and Odell, 1971). Controlled trials are still required to assess which of the available therapies would produce the best result and which has least unwanted effects. In our trial, no sleepiness has been noted at the present dosage of $8 \mathrm{mg} / \mathrm{kg}$ per day of phenobarbitone. Though phenobarbitone induces other enzymes apart from glucuronyl transferase, we have not noted any increase in the incidence of haemorrhagic disease, as postulated by Wilson (1969), nor any effect due to increased excretion of other drugs or steroids (Conney, 1967).

In conclusion we think that a small reduction in peak serum bilirubin level has been produced by phenobarbitone treatment in our series. This was achieved without noticeable side effects and probably is clinically worth while.

We gratefully acknowledge the willing co-operation of the paediatric nursing staff under the supervision of Miss M. Turner, R.G.N., S.C.M., the paediatric residents, and paediatric biochemistry laboratory (Dr. R. W. Logan). We thank Professor J. H. Hutchison for his help and co-operation in this study which was carried out on his patients.

\section{REFERENCES}

Ackerman, B. D., Dyer, G. Y., and Leydorf, M. M. (1970). Hyperbilirubinemia and kernicterus in small premature infants. Pediatrics, 45, 918.

Arias, I. M. (1970). Enzyme induction. Read at symposium held in the School of Pharmacy, London, 3 July 1970, organized by the Medical Research Society.

Armitage, P. (1960). Sequential Medical Trials, p. 67. Blackwell, Oxford.

Boggs, T. R., Hardy, J. B., and Frazier, T. M. (1967). Correlation of neonatal serum total bilirubin concentrations and developmental status at age 8 months. Fournal of Pediatrics, 71, 553. 
Broughton, P. M. G., Rossiter, E. J. R., Warren, C. B. M., Goulis, G., and Lord, P. S. (1965). Effect of blue light on hyperbilirubinaemia. Archives of Disease in Childhood, 40, 666.

Brown, A. K., and Zuelzer, W. W. (1958). Studies on the neonatal development of the glucuronide conjugating system. Fournal of Clinical Investigation, 37, 332.

Catz, C., and Yaffe, S. J. (1962). Pharmacological modification of bilirubin conjugation in the newborn. American fournal of Diseases of Children, 104, 516.

Conney, A. H. (1967). Pharmacological implications of microsomal enzyme induction. Pharmacological Reviews, 19, 317.

Culley, P., Powell, J., Waterhouse, J., and Wood, B. (1970). Sequelae of neonatal jaundice. British Medical fournal, 3, 383.

Cunningham, M. D., Mace, J. W., and Peters, E. R. (1969). Clinical experience with phenobarbitone in icterus neonatorum. Lancet, 1, 550.

Davies, O. L. (1960). The Design and Analysis of Industrial Experiments, p. 75 Table L3. Oliver and Boyd, Edinburgh.

Gartner, L. M., Snyder, R. N., Chabon, R. S., and Bernstein, J. (1970). Kernicterus: high incidence in premature infants with low serum bilirubin concentrations. Pediatrics, 45, 906.

Hunter, J., Thompson, R. P. H., Rake, M. O., and Williams, R. (1971). Controlled trial of phetharbital, a non-hypnotic barbiturate, in unconjugated hyperbilirubinaemia. British Medical fournal, 2, 497.

Hyman, C. B., Keaster, J., Hanson, V., Harris, I., Sedgwick, R., Wursten, H., and Wright, A. R. (1969). C.N.S. abnormalities after neonatal hemolytic disease or hyperbilirubinemia. American fournal of Diseases of Children, 117, 395.

Kerr, M. M., Logan, R. W., Cant, J. S., and Hutchison, J. H. (1971). Galactokinase deficiency in a newborn infant. Archives of Disease in Childhood, 46, 864.

Khanna, N. N., Harpur, E. R., and Stern, L. (1969). In vitro effect of sodium phenobarbital and diethyl-nicotinamide (coramine) on the protein-binding of bilirubin. Clinical Biochemistry, 2, 349.

Levin, G. E., McMullin, G. P., and Mobarak, A. N., (1970). Controlled trial of phenobarbitone in neonatal jaundice. Archives of Disease in Childhood, 45, 93.

Maurer, H. M., Wolff, J. A., Finster, M., Poppers, P. J., Pantuck, E., Kuntzman, R., and Conney, A. H. (1968). Reduction in concentration of total serum-bilirubin in offspring of women treated with phenobarbitone during pregnancy. Lancet, 2, 122.
Mertz, J. E., and West, C. D. (1956). A rapid micromethod for the determination of indirect bilirubin. American fournal of Diseases of Children, 91, 19.

Odell, G. B., Storey, G. N. B., and Rosenberg, L. A. (1970). Studies in kernicterus: III the saturation of serum proteins with bilirubin during neonatal life and its relationship to brain damage at five years. Fournal of Pediatrics, 76, 12

Poland, R. L., and Odell, G. B. (1971). Physiologic jaundice: the enterohepatic circulation of bilirubin. New England fournal of Medicine, 284, 1.

Ramboer, C., Thompson, R. P. H., and Williams, R. (1969). Controlled trials of phenobarbitone therapy in neonatal jaundice. Lancet, 1, 966.

Rawlings, G., Reynolds, E. O. R., Stewart, A., and Strang, L. B. (1971). Changing prognosis for infants of very low birthweight. Lancet, 1, 516.

Stahlman, M. (1969), What evidence exists that intensive care has changed the incidence of intact survival ? Ross Pediatric Research Conference, 59.

Stern, L., Khanna, N. N., Levy, G., and Yaffe, J. J. (1970). Effect of phenobarbital on hyperbilirubinemia and glucuranide formation in newborns. American fournal of Diseases of Children, 120, 26.

Thompson, R. P. H., Stathers, G. M., Pilcher, C. W. T., McLean, A. E. M., Robinson, J., and Williams, R. (1969). Treatment of unconjugated jaundice with dicophane. Lancet, $2,4$.

Trolle, D. (1968a). Phenobarbitone and neonatal icterus. (Letter.) Lancet, 1, 251.

Trolle, D. (1968b). Decrease of total serum-bilirubin concentration in newborn infants after phenobarbitone treatment. Lancet, 2, 705.

Trolle, D. (1968c). A possible drop in first-week-mortality rate for low birth-weight infants after phenobarbitone treatment. Lancet, $2,1123$.

Wilson, J. T. (1969). Phenobarbital in the perinatal period. Pediatrics, 43, 324.

Yeung, C. Y., and Field, C. E. (1969). Phenobarbitone therapy in neonatal hyperbilirubinaemia. Lancet, 2, 135.

Correspondence to Dr. F. Carswell, Department of Child Health, Royal Hospital for Sick Children, Yorkhill, Glasgow G3 8SJ. 